\title{
Copper Artifacts from Caddo Sites in the Southern Caddo Area
}

\author{
Jeffery S. Girard
}

Northwestern State University of Louisiana

Timothy K. Perttula

Heritage Research Center, Stephen F. Austin State University

Follow this and additional works at: https://scholarworks.sfasu.edu/ita

Part of the American Material Culture Commons, Archaeological Anthropology Commons, Environmental Studies Commons, Other American Studies Commons, Other Arts and Humanities Commons, Other History of Art, Architecture, and Archaeology Commons, and the United States History Commons

Tell us how this article helped you.

This Article is brought to you for free and open access by the Center for Regional Heritage Research at SFA ScholarWorks. It has been accepted for inclusion in Index of Texas Archaeology: Open Access Gray Literature from the Lone Star State by an authorized editor of SFA ScholarWorks. For more information, please contact cdsscholarworks@sfasu.edu. 


\section{Copper Artifacts from Caddo Sites in the Southern Caddo Area}

Creative Commons License

(c) (i) (8)

This work is licensed under a Creative Commons Attribution-NonCommercial 4.0 International License 


\title{
Copper Artifacts From Caddo Sites in THE Southern CAdDo AREA
}

\section{Jeffrey S. Girard and Timothy K. Perttula}

\begin{abstract}
Copper artifacts have been found at only 18 Caddo sites in the southern Caddo area of Southwest Arkansas, Northwest Louisiana, southeastern Oklahoma, and East Texas. Most of these exotic copper artifacts are found in burial mound context in important civic-ceremonial centers, or in burials in non-mound cemeteries. About 80 percent of the known copper artifacts occur in contexts in sites that date to the Early Caddo period (ca. A.D. 1000-1200). These copper items likely are linked to the Cahokia exchange system, and represent prestige goods with ritual status acquired and displayed by leaders in different Caddo communities. By Late Caddo period times (ca. A.D. 1400-1680), copper items tend to be ear spools, especially copper-covered stone ear spools. Copper continued to be used as personal ornaments linked to specific Caddo individuals, but they no longer served for objects that may have been involved in public ritual, as there are no effigies, sheet copper hand cutouts, or maskettes from Late Caddo contexts as there were in Early or Middle Caddo period contexts.
\end{abstract}

\section{Introduction}

Copper artifacts are amongst the rarest of items found on ancestral Caddo sites in the southern Caddo area. In over 100 years of archaeological investigations they have been documented from only18 different sites in Southwest Arkansas, Northwest Louisiana, southeastern Oklahoma, and East Texas (Figure 1). Although a few have been recovered from habitation contexts at Caddo mound sites, most copper artifacts have been found in burial mound contexts, or in burials in non-mound cemeteries.

There are no local sources of copper in the southern Caddo area, and the copper artifacts must have been obtained in exchange or trade with groups in the Midwest (particularly Cahokia) or Southeastern regions of North America with access to workable Lake Superior copper and with the artisans that could manufacture the copper objects (see Girard et al. 2008). The copper artifacts on Caddo sites represent prestige goods with ritual status, "items widely recognized as imparting power or wealth" (Girard et al. 2014:32) that were acquired and displayed by leaders in different Caddo communities. These same artifacts were then placed in close association with individuals in single graves or with groups of individuals in large tombs. 


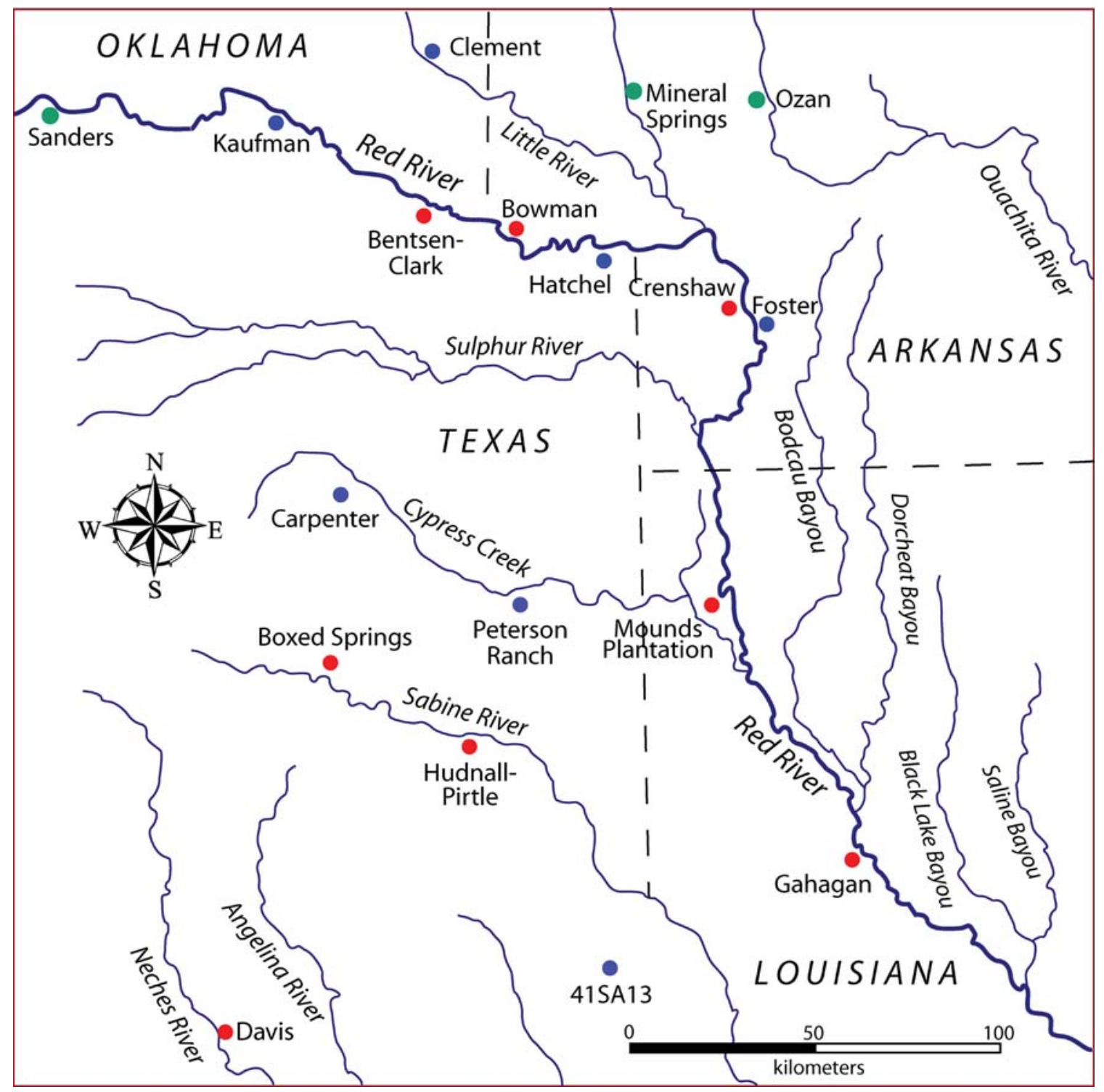

Figure 1. Caddo sites in the southern Caddo area with copper artifacts. Red dots are sites that date between ca. A.D. 900 to ca. A.D. 1200; green dots are sites that date from ca. A.D. 1200-1400; and the blue dots are sites that have components that date from ca. A.D. 1400 to the early 18th century A.D.

\section{Copper Artifact Finds}

The 18 ancestral Caddo sites with copper artifacts occur primarily in East Texas (56 percent), followed by sites in Southwest Arkansas (28 percent), Northwest Louisiana (11 percent), and southeastern Oklahoma (6 percent) (Table 1). Most of these sites are in the Red River drainage basin in all four states, but other Caddo sites with copper artifacts are known in the Ouachita River basin in Southwest Arkansas, and the Big Cypress, Neches, and Sabine River basins in East Texas.

There is a wide range of copper artifacts on ancestral Caddo sites (see Table 1). Included are ear spools of stone, wood, or shell with a copper covering; effigy hairpins; effigies; sheet copper cutouts; celts; copper needles and pins; bangles; beads and copper-covered beads; a copper cylinder; long nose god maskettes (see Girard et al. 2014:Figure 2.3); copper-covered wood rattles; and perforated or embossed copper strips (Figure 2). 


\begin{tabular}{|c|c|c|c|c|c|}
\hline Site & Period & General Context & Item & Class & Reference \\
\hline $41 \mathrm{SA} 13$ & late & surface & copper-plated hematite ear spools & ear ornaments (stone) & Perttula 2015b:50 and Figure 6 \\
\hline Bentsen Clark & early & $\begin{array}{l}\text { Feature } 1 \\
\end{array}$ & 2 shale ear spools with copper sheet covering & ear ornaments (stone) & Banks and Winters 1975 \\
\hline Bentsen-Clark & early & Feature 1 & 1 bone ear spool with copper overlay & ear ornaments (bone) & Banks and Winters 1975 \\
\hline Bentsen-Clark & early & Feature 1 & 1 limestone ear spool with copper sheet covering & ear ornaments (stone) & Banks and Winters 1975 \\
\hline Bentsen-Clark & early & Feature 1 & 2 snake effigy hairpins with copper overlays & effigy & Banks and Winters 1975 \\
\hline Bentsen-Clark & early & Feature 6 & 1 tapered piece of copper, possible hairpin covering & fragments & Banks and Winters 1975 \\
\hline Bentsen-Clark & early & Feature 6 & 1 rolled copper piece, possible overlay fragment & fragments & Banks and Winters 1975 \\
\hline Bowman & early & not known & copper celt & celt & AAS records, Chance Collection \\
\hline Bowman & early & not known & 2 stone ear spools covered with sheet copper & ear ornaments (stone) & AAS records, Spenser Collection \\
\hline Bowman & early & Mound 2 & 2 stone ear spools covered with sheet copper & ear ornaments (stone) & AAS records, Shirtleff Collection \\
\hline Bowman & early & not known & copper pin & needle or pin & AAS records, Chance Collection \\
\hline Boxed Springs & early & burial in non-mound cemetery & shell ear spools with an exterior spool copper covering & ear ornaments (shell) & Perttula 2011:210 and Figure A4.7 \\
\hline Clement & late & burial in temple mound & 2 stone ear spools covered with sheet copper & ear ornaments (stone) & Bell and Baerreis 1951:59 \\
\hline Crenshaw & early & Feature 6 & 14 small copper bangles & bangles/studs & AAS collections \\
\hline Crenshaw & early & Md. B, Burial 2 & copper covering to a shell ear spool; $9.0 \mathrm{~mm}$ in diameter & ear ornaments (shell) & Perttula et al. 2014:295 \\
\hline Crenshaw & early & Mound C & 2 copper ear ornaments, probably attached to wood & ear ornaments (wood) & Durham and Davis 1975:42 \\
\hline Crenshaw & early & Md. D, 1 ft. bs & sphere-shaped with drilled suspension hole, $17.5 \mathrm{~mm}$ diameter & fragments & Perttula et al. 2014:295 \\
\hline Crenshaw & early & Mound C & copper needle & needle or pin & Durham and Davis 1975:42 \\
\hline Foster Place & late & Burial 10 & 2 limestone ear ornaments with sheet copper on obverse sides & ear ornaments (stone) & Moore 1912:599 \\
\hline Foster Place & late & Burial 11 & 2 limestone ear ornaments with sheet copper on both sides & ear ornaments (stone) & Moore 1912:601 \\
\hline Gahagan & early & Mound A, Burial Pit 1 & tubular bead, presumably copper covered & bead & Moore 1912:514 \\
\hline Gahagan & early & Mound A, Burial Pit 1 & copper covered bead & bead & Moore 1912:514 \\
\hline Gahagan & early & Mound A, Burial Pit 1 & copper covered beads, possibly whole string & bead & Moore 1912:514 \\
\hline Gahagan & early & Mound A, Burial Pit 2 & copper beads & bead & Webb and Dodd 1939:96 \\
\hline Gahagan & early & Mound A, Burial Pit 2 & leather covered copper object & copper/leather ornament & Webb and Dodd 1939:96 \\
\hline Gahagan & early & Mound A, Burial Pit 1 & circular copper-covered wood ornament, 1.5 " dia. & copper/wood ornament & Moore 1912:514 \\
\hline Gahagan & early & Mound A, Burial Pit 1 & decayed sheet copper and wood & copper/wood ornament & Moore 1912:514 \\
\hline Gahagan & early & Mound A, Burial Pit 1 & $2^{\prime \prime}$ long cylinder of elm, $0.5^{\prime \prime}$ dia., copper coated & cylinder & Moore 1912:513 \\
\hline Gahagan & early & Mound A, Burial Pit 2 & 2 copper covered stone ear ornaments & ear ornaments (stone) & Webb and Dodd 1939:95 \\
\hline Gahagan & early & Mound A, Burial Pit 2 & 2 copper covered stone ear ornaments & ear ornaments (stone) & Webb and Dodd 1939:95 \\
\hline Gahagan & early & Mound A, Burial Pit 2 & 2 square copper covered cypress wood ear ornaments & ear ornaments (wood) & Webb and Dodd 1939:96 \\
\hline Gahagan & early & Mound A, Burial Pit 3 & 2 small copper covered ear ornaments of wood & ear ornaments (wood) & Webb and Dodd 1939:100 \\
\hline Gahagan & early & Mound A, Burial Pit 2 & $\begin{array}{l}\text { "five copper-covered wood pendants which have the shape of } \\
\text { animal claws" }\end{array}$ & effigy & Webb and Dodd 1939:99 \\
\hline Gahagan & early & Mound A, Burial Pit 1 & sheet copper represented only by small fragments & fragments & Moore 1912:512 \\
\hline Gahagan & early & Mound A, Burial Pit 1 & two decayed small ornaments of sheet copper & fragments & Moore 1912:513 \\
\hline Gahagan & early & Mound A, Burial Pit 1 & badly decayed ornament of sheet-copper and wood & fragments & Moore 1912:514 \\
\hline Gahagan & early & Mound A, Burial Pit 1 & traces of sheet copper & fragments & Moore 1912:514 \\
\hline Gahagan & early & Mound A, Burial Pit 2 & "several unrecognizable copper forms" & fragments & Webb and Dodd 1939:99 \\
\hline Gahagan & early & Mound A, Burial Pit 2 & 2 long nose god maskettes & maskettes & Webb and Dodd 1939:96 \\
\hline Gahagan & early & Mound A, Burial Pit 1 & copper covered wood rattle & rattle & Moore 1912:514 \\
\hline Gahagan & early & Mound A, Burial Pit 1 & crushed copper-covered wood ornaments, possibly rattles & rattle & Moore 1912:514 \\
\hline Gahagan & early & Mound A, Burial Pit 2 & 2 copper hands & sheet copper cutouts & Webb and Dodd 1939:96 \\
\hline Gahagan & early & Mound A, Burial Pit 2 & $\begin{array}{l}\text { "square plaque of sheet copper, centrally perforated and } \\
\text { embossed" }\end{array}$ & sheet copper cutouts & odd 1939:99 \\
\hline Gahagan & early & Mound A, Burial Pit 3 & square plaque of sheet copper, perforated and embossed & sheet copper cutouts & Webb and Dodd 1939:100 \\
\hline Gahagan & early & Mound A, Burial Pit 2 & copper strips & strips & Webb and Dodd 1939:96 \\
\hline George C. Davis & early & Mound C, & $\begin{array}{l}\text { fragment of tanned hide or skin with bark cloth and copper } \\
\text { staining }\end{array}$ & copper/leather ornament & Story \\
\hline George C. Davis & early & Mound C, Feature 134 & wood object with copper covering & copper/wood ornament & Story 1997 \\
\hline George C. Davis & early & Mound C. Feature 119 & thin sheet copper over disc-shaped wooden object & copperiwood ornament & Story 1997 \\
\hline George C. Davis & early & Mound C, Feature 119 & disc-shaped object of shell, wood, and copper & copper/wood ornament & Story 1997 \\
\hline George C. Davis & early & Mound C, Feature 119 & 2 copper-covered stone ear spools & ear ornaments (stone) & Story 1997 \\
\hline George C. Davis & early & Mound C, Feature 118 & 2 copper-covered stone ear spools & ear ornaments (stone) & Story 1997 \\
\hline George C. Davis & early & Mound C, Feature 155 & 2 copper-covered ear spools & ear ornaments (unknown) & Story 1997 \\
\hline George C. Davis & early & Mound C, Feature 161 & 2 copper-covered ear spools & ear ornaments (unknown) & Story 1997 \\
\hline George C. Davis & early & Mound C, Feature 119 & 1 copper-covered wooden ear spool & ear ornaments (wood) & Story 1997 \\
\hline George C. Davis & early & Mound C, Feature 155 & $\begin{array}{l}\text { wood object with cut mussel shell and copper overlays; shape } \\
\text { of canine tooth }\end{array}$ & effigy & Story 1997 \\
\hline George C. Davis & early & Mound C, Feature 119 & 1 disc-shaped piece of copper & fragments & Story 1997 \\
\hline George C. Davis & early & Mound C, Feature 119 & copper pieces adhering to turtle shells & fragments & Story 1997 \\
\hline George C. Davis & early & Mound C, Feature 119 & unidentified copper-covered object & fragments & Story 1997 \\
\hline George C. Davis & early & Mound C, Feature 119 & unidentified copper ornament in hair or on hairdress & fragments & Story 1997 \\
\hline George C. Davis & early & Mound C, Feature 118 & copper fragments around the skull & fragments & Story 1997 \\
\hline George C. Davis & early & Mound C, Feature 119 & bone pin with sheet copper overlay & needle or pin & Story 1997 \\
\hline George C. Davis & early & Mound C, Feature 155 & 1 copper-covered bone pin & needle or pin & Story 1997 \\
\hline Hatchel & $\begin{array}{l}\text { Eany } \\
\text { late }\end{array}$ & Zone $\mathrm{H}$, Platform Mound & 2 perforated copper strips & $\begin{array}{l}\text { strips } \\
\text { stats }\end{array}$ & \begin{tabular}{|l} 
Perttula $2014: 33$ and Figure 35 \\
\end{tabular} \\
\hline Hudnall-Pirtle & early & Unit 4 & small copper bead, possibly spherical in shape & bead & Bruseth and Perttula 2006:132 \\
\hline Mineral Springs & middle & Mound 6 & bits of copper stained wood & copper/wood ornament & Bohannon 1973:60 \\
\hline Mineral Springs & middle & Mound 6 & 2 stone ear spools covered with sheet copper & ear ornaments (stone) & Bohannon 1973:25 \\
\hline Mineral Springs & middle & not known & 2 embossed copper ear pendants & ear ornaments (unknown) & Harrington 1920:224 \\
\hline Mineral Springs & middle & Mound 2 & wood parrot head with copper scales & effigy & Harrington $1920: 90,220$ \\
\hline Mounds Plantation & early & Mound 5, Burial Pit 1 & 2 copper plated leather/wood ear ornaments & ear ornaments (wood) & Webb and McKinney 1975:103 \\
\hline Mounds Plantation & early & Mound 5, Burial Pit 2 & 2 copper plated wood ear ornaments & ear ornaments (wood) & Webb and McKinney 1975:103 \\
\hline Mounds Plantation & early & Mound 5, Burial Pit 1 & traces of copper & fragments & Webb and McKinney 1975:103 \\
\hline Mounds Plantation & early & Mound 5, Burial Pit 5 & traces of wood and copper & fragments & Webb and McKinney 1975:103 \\
\hline Mounds Plantation & early & Mound 5, Burial Pit 3 & traces of copper sheet, 8-10 $\mathrm{cm}$ across & fragments & Webb and McKinney 1975:104 \\
\hline Mounds Plantation & early & Mound 5, Burial Pit 6 & traces of copper & fragments & Webb and McKinney 1975:104 \\
\hline Mounds Plantation & early & Mound 5. Burial Pit 6 & traces of copper & fragments & Webb and McKinney 1975:104 \\
\hline Ozan & middle & Mound 5, Site 1 & circular copper ornaments on flattened circular object of wood & copper/wood ornament & Harrington 1920:224 \\
\hline Ozan & middle & Mound 5. Site 1 & embossed copper band or headress & sheet copper cutouts & Harrington $1920: 224$ \\
\hline Peterson Ranch & late & Burial 13 & 2 copper-covered ear spools with a cypress wood backing & ear ornaments (wood) & Perttula 2015a:3 \\
\hline Sam Kaufman & late & East Mound, shaft burial & 2 stone ear spools with copper overlay remnants & ear ornaments (stone) & Skinner et al. 1969:191 \\
\hline Sanders & middle & Burial B-20 & 2 spool shaped stone ear ornaments, copper on outside & ear ornaments (stone) & Jackson et al. $2000: 32,48,87$ \\
\hline Sanders & middle & NMNH Coll., surface & $12 \times 7 \times 4 \mathrm{~mm}$ copper fragment & fragments & Perttula et al. 2015 \\
\hline Tuck Carpenter & late & Burial 40 & 2 wooden disc-shaped objects covered with copper sheet & copper/wood ornament & Turner 1978:45 \\
\hline Tuck Carpenter & late & Burial 34 & 1 stone ear spool covered with sheet copper & ear ornaments (stone) & Turner $1978: 42$ \\
\hline
\end{tabular}

Table 1. Inventory of copper artifacts from Caddo sites in the southern Caddo area. 

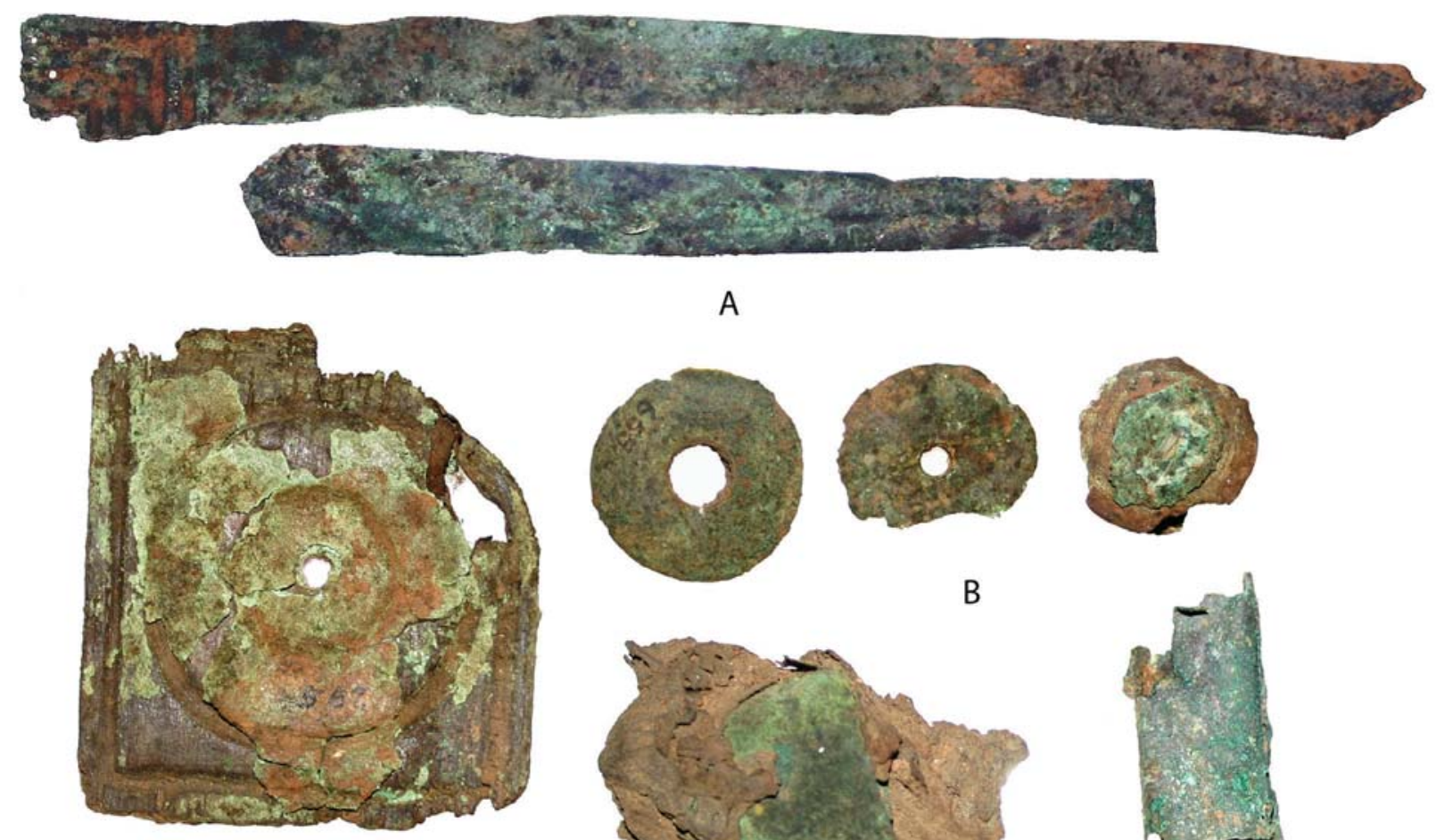

A

C

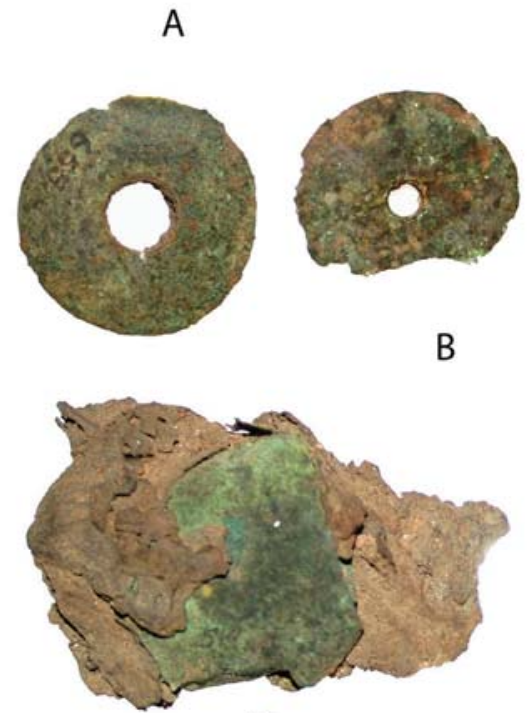

D
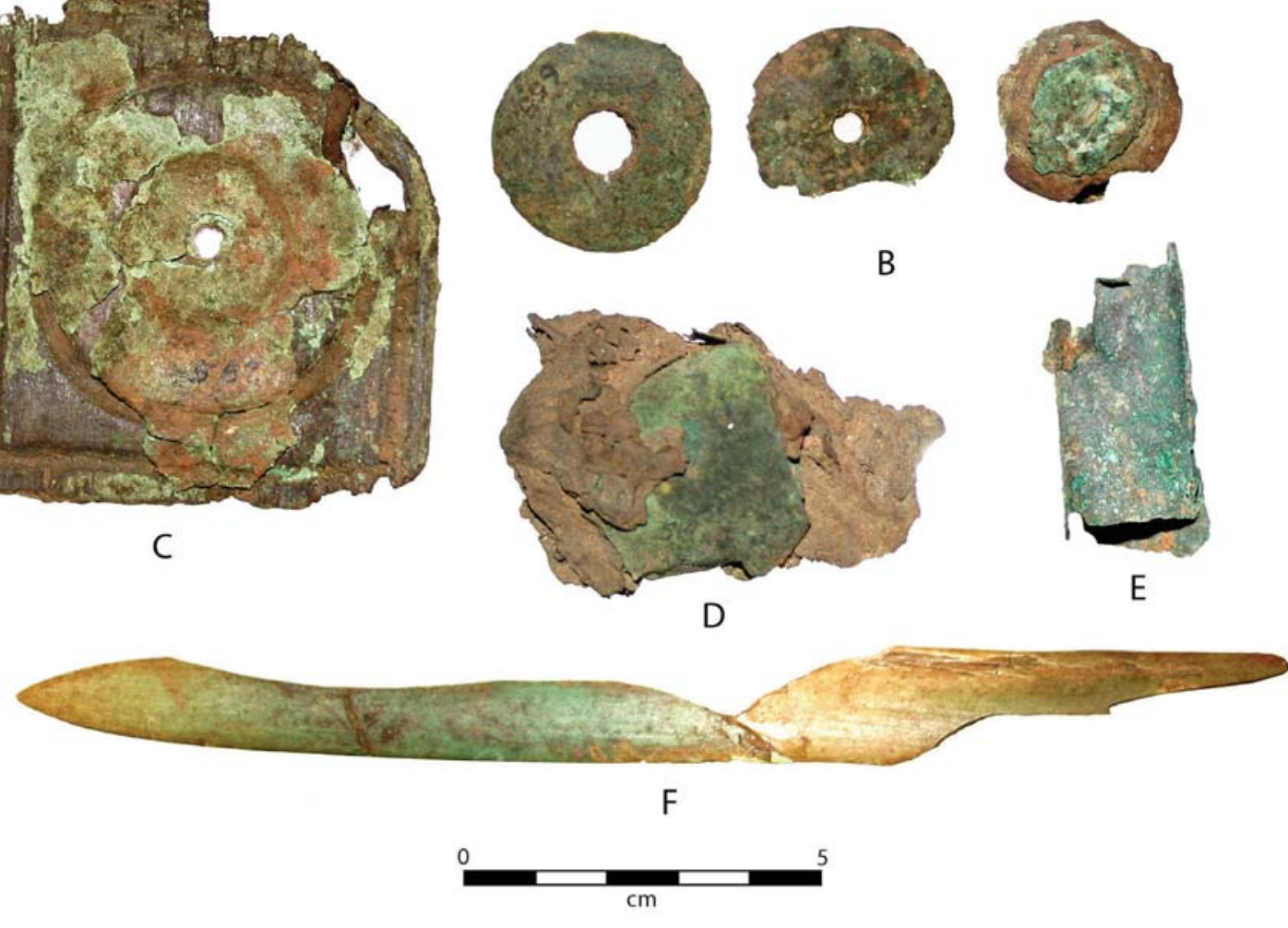

Figure 2. Examples of copper items from the Gahagan Site. A. copper strips; B. copper ear ornaments; C. copper ear ornament on wood; D. copper and leather item; E. copper cylinder; F. copper stained bone awl.

In terms of the temporal context, copper artifacts have been recovered from ancestral Caddo sites dating as early as the tenth century A.D. to as late as the late seventeenth -early eighteenth century A.D. About 44 percent of the sites with copper artifacts were occupied during the Early Caddo period, including BentsenClark, Bowman, Crenshaw, Gahagan, George C. Davis, Hudnall-Pirtle, Boxed Springs, and Mounds Plantation (see Table 1). With the exception of the Bentsen-Clark site, where copper artifacts were found in non-mound shaft tombs (Banks and Winters 1975), the other Early Caddo sites are large mound complexes in the Red, Neches, and Sabine river basins (Webb and Dodd 1939; Durham and Davis 1975; Webb and McKinney 1975; Story 1997; Bruseth and Perttula 2006; Perttula 2011). One of the few non-mortuary contexts yielding copper is at the Crenshaw site in the Great Bend region of the Red River in Southwest Arkansas. Small copper bangles or studs, likely part of a head dress, were recovered from the ash-laden floor of a large house, probably a ceremonial or priest's house. This house has been radiocarbon-dated to ca. A.D. 1190 (Samuelsen 2014).

Copper items are by far most abundant in sites that date to the Early Caddo period (Table 2), and their presence likely is linked to participation in the Cahokia exchange system. Regarding Cahokia, Girard et al. (2014:60) note-"Although it is not likely that interactions with Cahokia involved tribute, military threats, or 
direct economic influence, the presence of this massive place undoubtedly was known by Caddo Area peoples, and visitations, pilgrimages, and kinship connections with emigrants likely took place on a regular basis." A diverse array of objects occur in Early Caddo period contexts, but Late Caddo period copper items tend to be ear spools, especially copper-covered stone (see Tables 1 and 2). It appears that copper continued to be used as personal ornaments linked to specific individuals, but no longer had the same ritual significance, as there are no effigies, sheet copper hand cutouts, or maskettes from Late Caddo contexts.

\begin{tabular}{|c|c|c|c|c|}
\hline \multirow[b]{2}{*}{ Object Class } & \multicolumn{4}{|c|}{ Number of Contexts } \\
\hline & Early & Middle & Late & Total \\
\hline bangles/studs & 3 & & & 3 \\
\hline beads/cylinders & 6 & & & 6 \\
\hline celt & 1 & & & 1 \\
\hline sheet copper on wood & 5 & 2 & 1 & 8 \\
\hline ear ornaments, copper on bone & 1 & & & 1 \\
\hline ear ornaments, copper on shell & 2 & & & 2 \\
\hline ear ornaments, copper on stone & 8 & 2 & 6 & 16 \\
\hline ear ornaments, copper on wood & 6 & & 1 & 7 \\
\hline ear ornaments, copper on unknown material & 2 & 1 & & 3 \\
\hline effigies & 3 & 1 & & 4 \\
\hline needles or pins & 4 & & & 4 \\
\hline rattles & 2 & & & 2 \\
\hline sheet copper cutouts or strips & 4 & 1 & 1 & 6 \\
\hline unidentified fragments & 21 & 1 & & 22 \\
\hline Totals & 68 & 8 & 9 & 85 \\
\hline
\end{tabular}

Table 2. Context of copper artifacts in Caddo sites of Early, Middle, and Late Caddo periods.

\section{The Gahagan Site}

Within the southern Caddo area, copper items from the Gahagan site in Red River Parish, Louisiana, appear to be especially numerous and of exceptionally high quality. Among the recovered specimens are two long nose god maskettes, a cut sheet copper human hand symbol, and embossed copper ear ornaments pressed onto both cypress wood and stone. Other items include copper-covered wood and stone ear spools, a second sheet copper hand symbol, copper-covered wood beads, copper-plated marine shell fragments, cut strips of sheet copper, rolled copper cylinder fragments, and polished bone ornaments with copper staining.

All of these items were recovered in deep shaft graves sunk into a single burial mound (designated Mound A) that was destroyed during the 1940s by a shift in the Red River. The Gahagan site was first described by C. B. Moore in 1912, who stated that large numbers of mound remnants were scattered throughout the fields in the area (Moore 1912). However, in 1938, Clarence Webb and Monroe Dodd noted only one substantial mound (Mound A), two low rises (Mounds B and C), and numerous circular sandy areas that contained pottery (Webb and Dodd 1939). Mound A had been cut in half at the time a visit to the site was made by Webb and Alex Krieger in 1947, and subsequently the mound was completely destroyed by the river. It is not certain that the two low rises were constructed earthworks. One rise apparently was taken by the river and the fate of the other is unknown.

C. B. Moore excavated Burial Pit 1 in the center of the mound. The pit contained the remains of four individuals, one of which with arms and legs splayed out in a distinct position that is replicated in several other Early Caddo period shaft graves. This is the only individual with clearly associated grave goods. Other grave goods were placed along the northwest side of the burial pit. Several copper-covered wood and cut sheet copper ornaments were included among the grave goods, most of which were in too poor condition to identify as to form. The presence of Holly Fine Engraved and Hickory Engraved ceramic vessels indicates an Early Caddo period date for the grave. 
In 1938, Webb and Dodd excavated two more burial pits in Mound A before its destruction by the river. The largest was Burial Pit No. 2, which extended down ca. $2.4 \mathrm{~m}$ from the summit and had a level floor of white and yellow sand. Across the center of the pit was a row of six individuals, with a seventh skeleton laying perpendicular to the row. The central figure in the main row appeared to have been interred later than the others and was in the distinctive bow-legged position. Artifacts associated with the individuals were sparse, consisting only of copper-covered stone or wood ear ornaments and two caches of arrow points. As in Burial Pit No. 1, however, the northwest edge of the pit contained multiple clusters of items, including many of the distinctive stone bifaces now known as Gahagan bifaces. Among the burial goods were a human effigy pipe carved from distinctive CBP Missouri flint clay (Emerson et al. 2003; Emerson and Girard 2004), two human hand effigies of sheet copper, and two copper long nose god maskettes.

Burial Pit No. 3 contained a row of three individuals. Although most artifacts were placed along the northwest margin of the pit, found on the south side were a large Gahagan biface and a stone effigy pipe (a frog holding a rattle) also made of CBP Missouri flint clay, a likely import from the Cahokia area. The eastern portion of the grave was empty, apparently intended for persons not yet deceased who never were placed there.

Although excavations at Gahagan were conducted prior to the development of radiocarbon analyses, Emerson and Girard (2004) obtained permission from the Caddo Nation of Oklahoma to submit for dating small pieces of charred wood and leather that had become detached from three specimens recovered from Burial Pit No. 2. The results indicate that the items date to the late eleventh or early twelfth enturies A.D., suggesting direct contact between the southern Caddos and American Bottom populations during the Lohman or Sterling phases when Missouri flint clay figures were manufactured and in use at Cahokia.

\section{George C. Davis Site}

Mound C at the George C. Davis site is a special mortuary where the social, political, and religious elite of the Caddo community were buried in large and elaborate shaft tombs (Story 1997:64-65). Some of these burials had grave offerings of copper artifacts (see Table 1).

Six stages (I-VI) of tombs were found within the mound. The first stage (Feature 134) is a sub-mound burial, and Stages II-VI represent mound surfaces from which different shaft tombs originated. Although the burial features and construction of Mound $\mathrm{C}$ are not well dated by radiocarbon assays, the six stages of burials and mound surfaces may have been in use for ca. 250 or more years, from perhaps as early as $1010 \pm 80$ years B.P. (cal. A.D. 903-1157 at 2 sigma) to at least $770 \pm 80$ years B.P. (cal. A.D. 1163-1299, 2 sigma).

Copper artifacts were found as grave goods in Stage I-IV burials; most are from the Stage II burials: Feature 119 and Feature 155. The Stage I burial feature (Feature 134, with eight individuals) had a wood artifact with a copper covering. Both Stage III and IV burial features (Features 161 and 118, each with one individual) had two copper-covered earspools, and small fragments of copper were found around the skull of Feature 118, suggesting that a copper ornament had been in the hair of the deceased.

Feature 119 (with four individuals) in Stage II of the mound had two layers of burial offerings (Story 1997:29-38), both with copper artifacts. In the first or upper layer of offerings were a disc-shaped wooden object covered in thin sheet copper, fragments of thin sheet copper, and a small disc-shaped piece of copper.

The second or lower layer of offerings in Feature 119 included small pieces of copper adhering to turtle shells, possibly part of a turtle shell rattle, an unidentified copper-covered object, two copper-covered earspools, sheet copper associated with a bone pin, a disc-shaped ornament made of shell, wood, and copper, and a possible copper-covered wooden earspool. Copper salts identified around the skull of one of the individuals in this tomb suggests that this individual had a hair ornament containing copper.

Feature 155 (with one individual) in Stage II had several copper artifacts placed in the tomb as funerary offerings (Story 1997:41-42). These included two copper-covered earspools, a bone pin with a copper-covered bone ornament fitted over one end, and a small wood object overlain with a mosaic of cut mussel shells and copper pieces. 
Three pieces of copper were also recovered in the platform mound (Mound A) at the George C. Davis site (see Table 1). Two came from the floor of Feature 31, a large (15.2 $\mathrm{m}$ in diameter) and likely special purpose circular structure that lay under the south end of the first mound platform in Mound A (Newell and Krieger 1949:32-35). This structure in turn was constructed over two smaller oval to round houses built and then burned in a ca. $0.6 \mathrm{~m}$ deep depression. The other piece of copper came from floor deposits of Feature 9, another special purpose structure that was built along the north side of Mound A (Newell and Krieger 1949:179). This unique structure, $11.3 \mathrm{~m}$ in diameter, was built in a ca. $35 \mathrm{~cm}$ pit and had post-filled trenches and a clay floor as well as a clay-filled extended entranceway (Newell and Krieger 1949:Figure 11) pointing towards the central crest of Mound A.

Also at George C. Davis, four small fragments of copper were recovered during excavations in domestic areas in Units 65 and 109 between Mounds B and C. Baskin (1981:250) suggests they may be fragments of manufacturing debris.

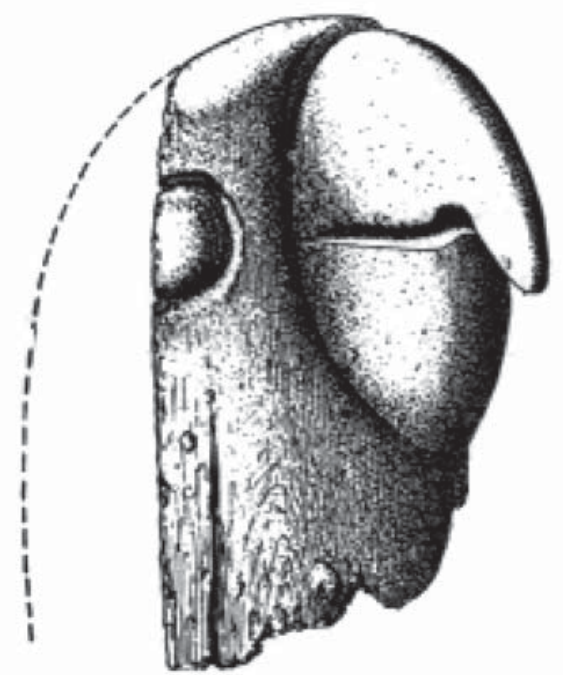

Figure 3. Copper-coated wood parrot or parakeet head from Mound 2 at the Mineral Springs site (Harrington 1920:Figure 32).

\section{Later Contexts}

Only about 17 percent of the Caddo sites with copper artifacts were occupied primarily in the Middle Caddo period (ca. A.D. 1200-1400). These are the Mineral Springs, Ozan Site 1, and Sanders sites in the Red and Ouachita River basins (Harrington 1920; Bohannon 1973; Jackson et al. 2000). All are multiple mound sites. Objects from these sites include circular copper ornaments and an embossed copper band or headdress from Ozan Site 1, copper-covered stone earspools at the Sanders site, and copper ear pendants, covered-covered stone earspools, and a wood parrot or parakeet head coated with copper (Figure 3) from the Mineral Springs site.

Six sites with copper artifacts were occupied in the Late Caddo period (ca. A.D. 1400-1680), including the Clement, Foster, Sam Kaufman, Tuck Carpenter, Hatchel, and 41SA13 in the Red, Big Cypress, and Neches drainage basins. These sites include both mound centers (Moore 1912; Bell and Baerreis 1951; Skinner et al. 1969; Regnier et al. 2013) as well as non-mound cemeteries (Turner 1978; Perttula 2015b).

Finally, the Peterson Ranch site (41HS253) in the Little Cypress stream basin in East Texas is a large non-mound cemetery (Perttula 2015a) that was used by ancestral Caddo peoples in the early historic period, from ca. A.D. 1680-1720. One of the burials at the site was accompanied by two copper-covered ear spools with cypress wood backing.

\section{Summary and Conclusions}

Copper artifacts of various forms and types have been found at only 18 Caddo sites in the southern Caddo area of Southwest Arkansas, Northwest Louisiana, southeastern Oklahoma, and East Texas. Items include copper long nose god maskettes, cut sheet copper symbols in the form of human hands, copper ear ornaments, copper-covered bone needles or hairpins, embossed copper head ornaments, beads and bangles, a small copper celt, copper-covered wood and turtle shell rattles, a wood parrot or parakeet plated with copper, copper-covered wood and shell items in the shape of animal claws and teeth, and fragments of rolled copper tubes or cylinders. By far the most common kind of copper artifacts on Caddo sites, regardless of age, are copper-covered ear ornaments or ear spools. 
Most of these exotic copper artifacts are found in burial mound context in important civic-ceremonial centers such as the Gahagan site on the Red River in Northwest Louisiana and the George C. Davis site on the Neches River in East Texas, or in burials in non-mound cemeteries like that excavated at the Bentsen-Clark site on the Red River in East Texas. There are only a few instances where copper artifacts have been found in non-mortuary contexts, most notably in the ca. A.D. 1190 ash bed of a possible ceremonial or priest's house at the Crenshaw site on the Red River in Southwest Arkansas and in post-A.D. 1500 contexts in the large Nasoni Caddo platform mound at the Hatchel site on the Red River in East Texas.

About 80 percent of the known copper artifacts in the southern Caddo area occur in contexts in sites that date to the Early Caddo period (ca. A.D. 1000-1200). These copper items likely are linked to the Cahokia exchange system, and thus they represent prestige goods with ritual status acquired and displayed by leaders in a number of different Caddo communities. By Late Caddo period times (ca. A.D. 1400-1680) and in postA.D. 1680 Historic Caddo period times, copper items tend to be ear spools, especially copper-covered stone ear spools, recovered in mortuary contexts associated with individuals.

Although the role of copper in the Caddo world may have changed through time as a result of shifting relationships of Caddo Area groups with those in surrounding regions, as well as from transformations in connections between, and leadership roles within, Caddo societies, copper appears to have continued as a symbol of the elite status of a limited number of individuals into historic times. The demise of the Cahokia exchange system may have resulted in declining access to copper ornaments for Caddo Area communities and their leaders. Symbolically laden items probably displayed in public ritual such as the long nose god maskettes and cutouts of sheet copper no longer were available after the thirteenth century. However, these items never were abundant and most have been recovered from only a few sites, particularly the Gahagan site located along the southern margin of the Caddo Area. It is interesting that Gahagan does not appear to have been a particularly large or important regional center, and the reasons for burial of multiple exotic ritual items at that location remain mysterious.

\section{References Cited}

Banks, Larry D. and Joe Winters

1975 The Bentsen-Clark Site, Red River County, Texas: A Preliminary Report. Special Publication No. 2. Texas Archeological Society, San Antonio.

Baskin, Barbara J.

1981 Lithic and Mineral Artifacts. In Archeological Investigations at the George C. Davis Site, Cherokee County, Texas: Summers of 1979 and 1980, edited by Dee Ann Story, pp. 239-320. Occasional Papers, No. 1. Texas Archeological Research Laboratory, The University of Texas at Austin.

Bell, Robert E. and David A. Baerreis

1951 A Survey of Oklahoma Archaeology: Bulletin of the Texas Archeological and Paleontological Society 22:7-100.

Bohannon, Charles F.

1973 Excavations at the Mineral Springs Site, Howard County, Arkansas. Research Series No. 5. Arkansas Archeological Survey, Fayetteville.

Bruseth, James E. and Timothy K. Perttula

2006 Archeological Investigations at the Hudnall-Pirtle Site (41RK4): An Early Caddo Mound Center in Northeast Texas. Caddo Archeological Journal 15:57-158.

Durham, James H. and Michael K. Davis

1975 Report on the Burials Found at Crenshaw, Mound C, Miller County, Arkansas. Bulletin of the Oklahoma Anthropological Society 23:1-90. 
Emerson, Thomas E. and Jeffrey S. Girard

2004 Dating Gahagan and Its Implications for Understanding Cahokia-Caddo Interactions. Southeastern Archaeology 23(1):57-64.

Emerson, Thomas E., Randall E. Hughes, Mary R. Hymes, and Sarah R. Wisseman

2003 The Sourcing and Interpretation of Cahokia-Style Figurines in the Trans-Mississippi South and Southeast. American Antiquity 68(2):287-313.

Girard, Jeffrey S., David W. Morgan, and Timothy K. Perttula

2008 Copper Artifacts from Gahagan and Other Sites in the Southern Caddo Area. In "The Status of Copper Studies in the Greater Mississippian Southeast" symposium, 65 ${ }^{\text {th }}$ Annual Southeastern Archaeological Conference, Charlotte, North Carolina.

Girard, Jeffrey S., Timothy K. Perttula, and Mary Beth Trubitt

2014 Caddo Connections: Cultural Interactions within and beyond the Caddo World. Rowman \& Littlefield, Lanham, Maryland.

Harrington, Mark R.

1920 Certain Caddo Sites in Arkansas. Indian Notes and Monographs, Miscellaneous Series No. 10. Museum of the American Indian, Heye Foundation, New York.

Jackson, A. T., Marcus S. Goldstein, and Alex D. Krieger

2000 The 1931 Excavations at the Sanders Site, Lamar County, Texas: Notes on the Fieldwork, Human Osteology, and Ceramics. Archival Series 2. Texas Archeological Research Laboratory, The University of Texas at Austin.

Moore, Clarence. B.

1912 Some Aboriginal Sites on Red River. Journal of the Academy of Natural Sciences of Philadelphia 14(4):526-636.

Newell, H. Perry and Alex D. Krieger

1949 The George C. Davis Site, Cherokee County, Texas. Memoirs No. 5. Society for American Archaeology, Menasha, Wisconsin.

Perttula, Timothy K.

2014 Archaeological Studies of the Hatchel Site (41BW3) on the Red River in Bowie County, Texas. Special Publication No. 23. Friends of Northeast Texas Archaeology, Austin and Pittsburg.

2015a The Peterson Ranch Site (41HS253), A Late $17^{\text {th }}$ to Early $18^{\text {th }}$ Century Ancestral Caddo Cemetery in the Little Cypress Creek Basin, Harrison County, Texas. Journal of Northeast Texas Archaeology 54:1-7.

2015b Two Caddo Sites in the Attoyac Bayou Basin in the East Texas Pineywoods, San Augustine County, Texas. Journal of Northeast Texas Archaeology 54:41-53.

Perttula, Timothy K. (assembler)

2011 Archaeological and Archaeogeophysical Investigations at an Early Caddo Mound Center in the Sabine River Basin of East Texas, Special Publication No. 15. Friends of Northeast Texas Archaeology, Austin and Pittsburg.

Perttula, Timothy K., Bo Nelson, Mark Walters, and Robert Cast

2014 Documentation of Caddo Funerary Objects from the Crenshaw Site (3MI6) in the Gilcrease Museum Collections. Special Publication No. 19. Friends of Northeast Texas Archaeology, Pittsburg and Austin.

Perttula, Timothy K., Bo Nelson, Mark Walters, and Robert Z. Selden Jr.

2015 The Sanders Site (41LR2): A Middle to Historic Caddo Settlement and Mound Center on the Red River in Lamar County, Texas. Journal of Northeast Texas Archaeology 50:1-87. 
Regnier, Amanda L., Patrick C. Livingood, and Scott W. Hammerstedt

2013 The Last of WPA Archaeology in Oklahoma: The Clement and McDonald Sites. In Shovel Ready: Archaeology and Roosevelt's New Deal for America, edited by Bernard K. Means, pp. 110-126. University of Alabama Press, Tuscaloosa.

Samuelsen, John R.

2014 AMS and Radiocarbon Dating of the Crenshaw Site (3MI6). The Arkansas Archeologist 52:17-35.

Skinner, S. Alan, R. King Harris, and Keith M. Anderson (editors)

1969 Archaeological Investigations at the Sam Kaufman Site, Red River County, Texas. Contributions in Anthropology No. 5. Department of Anthropology, Southern Methodist University, Dallas.

Story, Dee Ann

1997 1968-1970 Archeological Investigations at the George C. Davis Site, Cherokee County, Texas. Bulletin of the Texas Archeological Society 68:1-113.

Turner, Robert L.

1978 The Tuck Carpenter Site and Its Relations to Other Sites within the Titus Focus. Bulletin of the Texas Archeological Society 49:1-110.

Webb, Clarence. H.

1959 The Belcher Mound, a Stratified Caddoan Site in Caddo Parish, Louisiana. Memoirs No. 16. Society for American Archaeology, Salt Lake City.

Webb, Clarence H. and Monroe Dodd, Jr.

1939 Further Excavations of the Gahagan Mound: Connections with a Florida Culture. Bulletin of the Texas Archeological and Paleontological Society 11:92-126.

Webb, Clarence H. and Ralph R. McKinney

1975 Mounds Plantation (16CD12), Caddo Parish, Louisiana. Louisiana Archaeology 2:39-127. 